Témoigner Témoigner. Entre histoire et mémoire

Getuigen Revue pluridisciplinaire de la Fondation Auschwitz

125 | 2017

Histoire et mémoire de la persécution des

homosexuel-le's par les nazis

\title{
De bestraffing van homoseksualiteit in Frankrijk tussen 1940 en 1945
}

La répression de l'homosexualité en France entre 1940 et 1945

Jean-Luc Schwab

Traducteur : Gorik de Henau

\section{(2) OpenEdition}

Journals

Édition électronique

URL : https://journals.openedition.org/temoigner/6500

DOI : 10.4000/temoigner.6500

ISSN : 2506-6390

Cet article est une traduction de :

La répression de l'homosexualité en France entre 1940 et 1945 - URL : https://

journals.openedition.org/temoigner/6470 [fr]

Éditeur :

Éditions du Centre d'études et de documentation Mémoire d'Auschwitz, Éditions Kimé

Édition imprimée

Date de publication : 1 octobre 2017

Pagination : 95-107

ISBN : 978-2-930953-01-4

ISSN : 2031-4183

Référence électronique

Jean-Luc Schwab, «De bestraffıng van homoseksualiteit in Frankrijk tussen 1940 en 1945», Témoigner. Entre histoire et mémoire [Online], 125 | 2017, Online op 24 décembre 2021, geraadpleegd op 04 février 2022. URL: http://journals.openedition.org/temoigner/6500 ; DOI: https://doi.org/10.4000/temoigner. 6500 


\section{De bestraffing van homoseksualiteit in Frankrijk tussen 1940 en 1945}

$\rightarrow$ Jean-Luc Schwab Vertaling uit het Frans: Gorik de Henau

Jean-Luc Schwab bestudeert de bestraffing van homoseksualiteit in Frankrijk tijdens de Tweede Wereldoorlog. Hij doet onderzoek in het raam van een proefschrift over deportatie om homoseksuele redenen naar het concentratiekamp Natzweiler. Daarnaast schreef hij een biografie van Rudolf Brazda (1913-2011), de laatste bekende overlevende van deportatie op grond van homoseksualiteit (Itinéraire d'un Triangle Rose, Parijs: Florent Massot, 2010/J'ai Lu, 2013).

\section{DE TERRITORIALE OPDELING VAN FRANKRIJK}

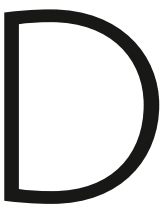
e vervolging van individuen die tijdens de Tweede Wereldoorlog in Frankrijk van homoseksualiteit werden beschuldigd is een onderwerp dat ook vandaag nog verbazend omstreden is. Om de zoveel tijd gaan voor- en tegenstanders van een nochtans niet meer te ontkennen realiteit publiekelijk met elkaar in de clinch, maar de details blijven grotendeels onbekend. In Frankrijk was de situatie niet overal dezelfde. Dat kwam doordat het naziregime op het ritme van zijn expansiedrift en oorlogspolitiek zijn eigen maatregelen ging opleggen buiten de territoriale grenzen van het Duitsland van na het verdrag van Versailles. In Duitsland zelf ging de aanvankelijk wettelijke bestraffing terug op artikel 175 van het (uit de keizertijd daterende) wetboek van strafrecht, waarvan de bepalingen in 1935 door het Hitlerregime waren verscherpt. Boven op die wet kwamen dwangpraktijken, vooral vanwege de politie. Heel dat strafarsenaal werd na de Duitse militaire annexaties en veroveringen als het ware 'geëxporteerd', zoals Florence Tamagne ook beschrijft in dit nummer. Maar de toepassing ervan verschilde al naargelang de gebieden die onder Duitse controle kwamen en het beleid dat de nazi's er voerden.

De bestraffing van homoseksuelen in Frankrijk varieerde naargelang de streek. Na de wapenstilstand van 22 juni 1940 werd het door de Duitse troepen overwonnen Frankrijk namelijk in drie hoofdzones ingedeeld. Een uitzondering vormden Corsica en een paar grensgebieden, die respectievelijk werden bezet door het fascistische Italië (in het zuidoosten) en onder het Duitse militaire bestuur in Brussel werden geplaatst (in het noorden). Dit zijn de drie zones:

\footnotetext{
- een bezette zone onder Duits bestuur, met ruwweg de departementen ten noorden van de Loire en een brede Atlantische kuststrook tot aan de Spaanse grens;

- de twee departementen Elzas en Moselle, die de facto waren geannexeerd;

- het resterende gebied in het zuiden: dit was de zetel van de Vichyregering en werd tot november 1942 de 'niet-bezette zone' of 'vrije zone' genoemd, toen ze door de Duitse autoriteiten preventief werd ingepalmd als gevolg van de geallieerde landing in Noord-Afrika.
} 
De bestraffing van
homoseksualiteit in Frankrijk binnenviel en de volledige bevrijding van het land, moeten dus worden begrepen in het licht van die territoriale opdeling. We zullen zien dat de bestraffing van homoseksualiteit verschilt al naargelang de houding die de Duitse en Franse autoriteiten in elk van die grote territoriale zones tegenover homoseksualiteit aannemen. Het aparte geval van de ingelijfde Elzas blijkt een essentiële sleutel om het fenomeen in Frankrijk te begrijen, zowel wat de geschiedenis als de gedachtenis betreft Want (Want door de geschiedenis te bestuderen kunnen we ook de collectieve en militante her-

\section{YOORAFGAAND AAN HET ONDERZOEK}

Willen we de vervolging van homoseksuelen in bezet of ingelijfd Frankrijk vanuit geschiedkundig oogpunt beschouwen, dan moeten we omzichtig omspringen met de wijze waarop dit alles tot in de jaren 2000 werd benaderd. Vooraf konden de belangrijkste auteurs van Franse geschriften over dit onderwerp, vaak activisten als Guy Hocquenghem, Jean Boisson of Jean Le Bitoux, zich niet bepaald beroepen op een groot antal che eengroon hedendaagse archieven in Frankrijk en Duitsland. Door een gebrek aan betrouwbare informatie hebben deze activisten van de homoseksuele emancipatie - lang de enigen die volhielden dat een dergelijke vervolging in Frankrijk had plaatsgevonden - hun opponenten niet altijd op overtuigende en gefundeerde wijze van antwoord gediend. Dit is vandaag nog altijd het geval, want de beweringen van bepaalde LGBT-activisten (lesbiennes, homo-, bi- en transseksuelen) steunen vaak op schattingen en overgenomen uitlatingen, zowel betreffende cijfers als beschikbare bronnen (Bourgi 2015, 356-363), terwijl ze de vervolging beperken tot de meest symbolische gedeporteerden met de roze driehoek. Maar uit de studie van archiefstukken blijkt juist dat de Duitse bezetter in zijn vervolgingspraktijk, als die met vrijheidsberoving gepard ging een voorkeur had voor andere detentiestructuren dan alleen maar concentraconcentratiekanpen. Als ze vor he moten we dus zoorichtig zijnmet wat de leidende figuren van de gedachtenis (de overheid, gedachtenisinstellingen en -verenigingen, mensen die om andere redenen werden gedeporteerd) en LGBT-activisten daarover hebben gezegd en geschreven Het eerste aanvaardbare onderzoek over Frankrijk is alles wel beschouwd zeer recent. Het is iets ouder wat Duitsland betreft, meer bepaald de door het Duitse Rijk ingelijfde gebieden en inclusief de drie al genoemde Franse departementen. Pas vanaf 2006 ondernam Arnaud Boulligny, onderzoeker bij de Franse Fondation pour la Mémoire de la Déportation, de eerste nauwkeurige studies. Hij begon de Fransen te tellen die beschuldigd werden van homoseksualiteit en die belandden in een concentratiekamp of op andere detentieplekken in Duitslanden op Franse bodem. van Defensie, dat bevoegd is voor het behandelen van naoorlogse aanvragen vanwege slachtoffers of hun rechthebbenden die het statuut van gedeporteerde of gevangene willen verkrijgen. Via zijn contacten bij de Duitse concentratiekampmemorialen en dankzij kopieën van documenten van de International Tracing Service (ITS) in Bad Arolsen kon hij een eerste lijst opstellen van Fransen die uitdrukkelijk als 'homoseksueel' werden aangeduid in de concentratiekampen, meer bepaald in het kamp Natzweiler (de verduitste naam van het Elzassische dorp Natzwiller waar het kamp oorspronkelijk was gevestigd en lokaal bekend als Struthof, de naam van het gehucht). Zijn publicaties zijn de enige warover we beschikken voor Frankrijk met uitzondering pubiter zing dus van het ingelijfde gebied. Voor dat laatste en de Elzas in het bijzonder zal ik me hoofdzakelijk baseren op mijn onderzoek in de archieven van de departementen Haut-Rhin en Bas-Rhin, de burgerlijke stand en diverse ongepubliceerde bronnen afkomstig uit gevangenissen en psychiatrische centra van instellingen die ook vandaag nog die functies vervullen (Schwab 2015). Ik consulteerde ook andere collecties in Duitsland, met name die van de ITS en sommige departementen van de voormalige onbezette zone. ${ }^{1}$ Voor het departement Moselle ten slotte kon ik het plaatje betreffende de ingelijfde zone vervolledigen via de inlichtingen die werden verzameld door de historicus Cédric Neveu (Neveu 2012).

\section{DE FRANSE CONTEXT}

Met het wetboek van strafrecht van 1791 en het feit dat sodomie na de Franse Revolutie niet langer als een misdaad gold, waren homoseksuele praktijken tussen mannen met wederzijdse instemming niet langer strafbaar volgens de Franse wet (Lever 1985). In het begin van de twintigste eeuw was homoseksualiteit als zodanig nog altijd niet verboden. Wel kon een procedure worden opgestart als de bezwarende elementen gewichtig genoeg waren om een zedenmisdrijf te vormen, een aanklacht die ook op andere praktijken dan homoseksualiteit sloeg.

Na het debacle van 1940 leidde maarschalk Pétain de Franse regering vanuit Vichy (onbezette zone), waarbij hij sinds 10 juliovervolmachten beschikte. Ondanks (n) de Duitse voogdij be in de departementen en regio's, ook in de bezette noordelijke zone. Op 6 augustus 1942 vaardigde het Vichyregime, in een geest van morele recuperatie die typerend was voor zijn 'nationale revolutie', een wet uit waardoor alle vrijwillige homoseksuele handelingen tussen meerderjarigen (tot en met 21 jaar) en minderjarigen van hetzelfde geslacht konden worden bestraft met een geldboete of een gevangenisstraf van meer dan dertien jaar. ${ }^{2}$ Aangezien soortgelijke bepalingen niet van toepassing waren voor heteroseksuele handelingen ontstond door de wet de facto discriminatie aangaande de seksuele meerderjarigheid voor homoseksuele handelingen. Ook nieuw was dat ze zowel voor mannelijke als vrouwelijke homoseksualiteit gold. In de zuidelijke zone zijn enkele gevallen bekend van procedures die uitmondden in veroordeling tot gevangenstrof (Boninchi 2005). Je zou denken dat deze wetgevero ving een beslissende invloed had in het land, maar ze ging niet gepaard met een grootschalige, systematische bestraffing Globale statistieken per jaar werden maar
(1) Archieven van het
departement Gers in Auch

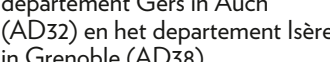

(2) Journal Officiel de la Republique française [Frans augustus 1942 tot wijiging van
artikel 334 van het wetboek van 
De bestraffing van
homoseksualiteit in Frankriik homoseksualiteit in Frant
tussen 1940 en 1945 tussen 1940 (vervolg)
(ver

bijgehouden vanaf 1945, toen het ministerie van Justitie alles bij elkaar 22 aanklachten voor 'homoseksuele misdrijven' opsomde. Maar veel bepalender voor de daaropvolgende jaren was het feit dat in het Franse recht in het geniep het concept 'tegennatuurlijke' handeling werd ingevoerd, waarmee de deur voor de stigmatisering van homoseksualiteit kwam open te staan (Jackson 2009). In dit verband vormde de periode 1940-1945 - jaren van bezetting, verlies van soevereiniteit en een regering die in een continentale oorlogscontext met de vijand collaboreerde een keerpunt voor Frankrijk. Het loont de moeite stil te stan bij de manier warop een keep

BESTRAFFING VANHOMOSEKSUALITEITEN

ADMINISTRATIEVE OPSLUITING IN DE ZUIDELIJKE ZONE

Hoewel de eerste gevolgen moeilijk te kwantificeren zijn, lijkt de door Vichy afgeroepen wet maar weinig effect te hebben gehad in de periode tussen de uitvaardiging ervan en de geleidelijke bevrijding van het Franse grondgebied tijdens de tweede helft van 1944, zelfs in de zuidelijke zone waar de regering van maarschalk Pétain zetelde. Toch brengt archiefmateriaal over administratieve opsluiting een ander type dwangmiddelen aan het licht tegen mannen die van homeksuliteit ( werden besch dus bijna twee jaar voór de invoering van de wet. Het principe van administratieve opsluiting stoelde op het decreet van 18 november 1939, dat erop gericht was 'individuen die een gevaar inhouden voor de nationale defensie of de openbare veiligheid te neutraliseren; zij moesten worden verwijderd uit hun woonplaats en gedurende een periode van beleg zelfs op een speciale plek verblijven. ${ }^{3}$ De maatregel werd herzien en aangepast door Vichy en werd in eerste instantie uitgevaardigd door de prefecten. Die laatsten beslisten op politievoorstel over opsluiting voor bepaalde duur in een Centre de séjour surveillé (CSS), waarbij de verwijdering met verplich verblijf een alternatief bleef.

Uit de studie van de betreffende stukken in de archieven van het departement De politierechercheurs waren geneigd om strenger te zijn bij bepaalde inbreuken op de openbare orde, vooral losbandigheid en openbare dronkenschap, als er sprake was van homoseksualiteit als verzwarende factor voor de deugdzaamheid van een individu. Dit was bijvoorbeeld het geval bij Lucien Meyer (1909-1943), die in mei 1941 door een politieagent uit Gers 'ongewenst' werd genoemd: 'Het zou nuttig zijn hem te laten opsluiten in een centrum onder toezicht', want hij 'staat erom bekend dat hij losse zeden heeft en verslingerd is aan de drank'. In de verordening van de prefect kort daarna - nauwelijks dertien dagen na zijn aankomst in het departement, want hij was wegens homoseksualiteit uit de geannexeerde Elzas gezet - werd bovendien verduidelijkt dat hij 'van twijfelachtige zeden' was en 'in staat zich om het even waar aan zijn aparte zeden over te geven'. ${ }^{4} \mathrm{Hij}$ werd eerst naar het CSS van Sisteron in het departement Basses-Alpes gestuurd, waar hij bijna anderhalfjaar zou

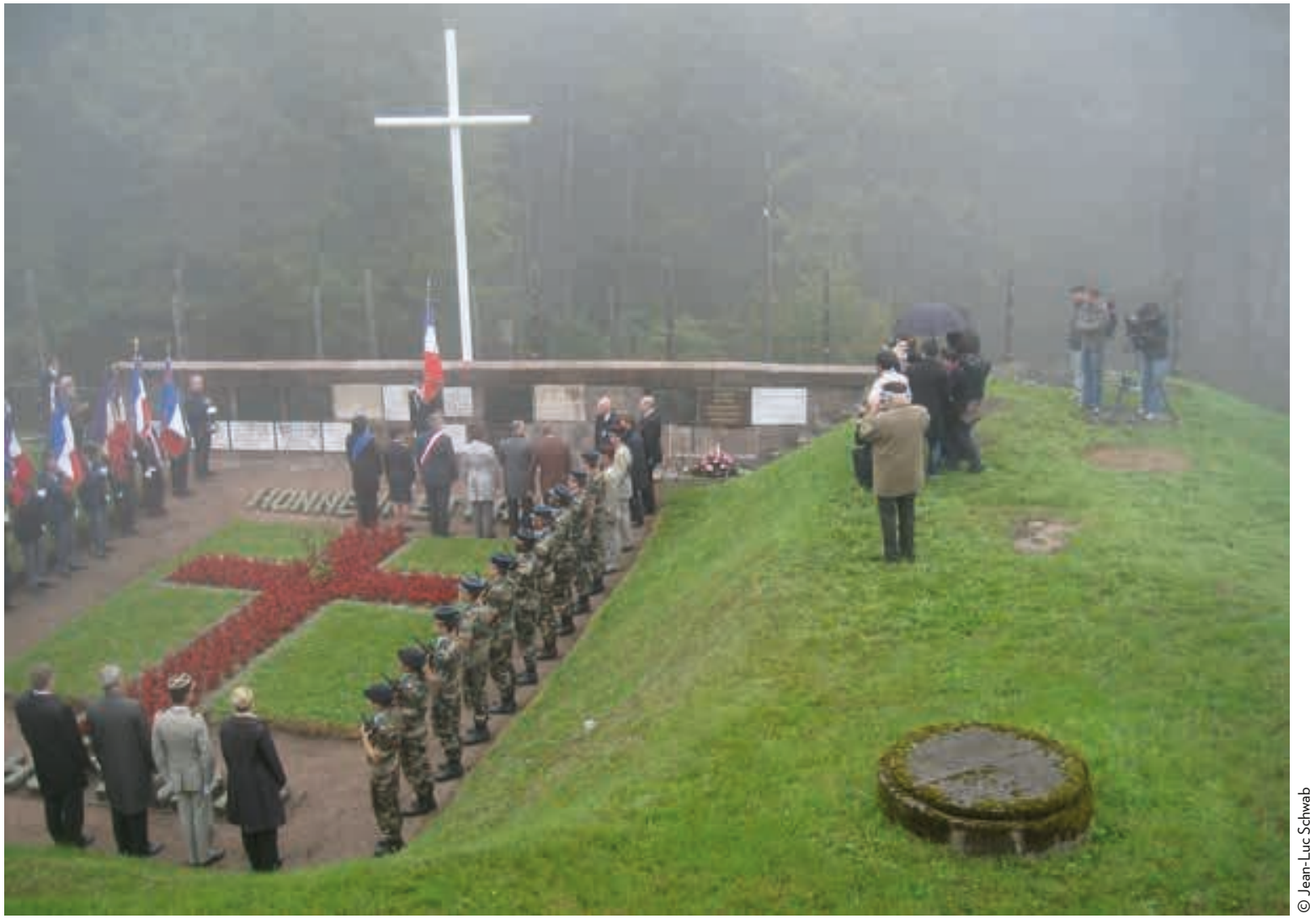

blijven, en medio november 1942 overgebracht naar het CSS van Fort Barraux in het departement Isère. Toen al maakte de administratie zich zorgen over zijn zwakke gezondheid. Ironisch genoeg arriveerde het besluit waardoor zijn administratieve opsluiting werd omgezet in een verplicht verblijf in Gers nauwelijks een paar dagen na zijn overlijden, op 1 februari 1943 in de ziekenboeg van het CSS. ${ }^{5}$

Er zijn nog drie andere gevallen bekend van administratieve opsluiting opgelegd door de prefect van het departement Alpes-Maritimes in Nice, zowat aan het andere eind van de niet-bezette zone. Opnieuw passeerden de gevangenen via verschillende detentieplekken voor ze in het CSS van Sisteron en vervolgens in dat van Fort Barraux terechtkwamen. In het dossier van een van hen, Henry P. (1920-1975), opgesloten per verordening van de prefect d.d. 31 oktober 1940, beoordeelde de baas van het CSS in Fort Barraux hem als volgt: 'Het is een homoseksueel die beweert dat hij nog nooit heeft het individu nietva het individu 'niet van plan is na zijn vrijlating aan het werk te gaan' werd uiteindelijk een ongunstig advies uitgesproken, dat de beslissende overheden ook volgden. ${ }^{6} \mathrm{Op}$
- Inhuldiging van de herdenkingsplaat vo
de slachtoffers van deportatie op grond van homoseksualiteit. Voormalige kamp Natzweiler (Elzas)
25 september 2010 (a)

(5) AD 38, Grenoble,
afzonderlijke dossiers,

(6) $A D 30$, 
22 juni 1944 zaten hij en de andere betrokkenen op het transport van Grenoble naar het concentratiekamp Buchenwald, waar ze dwangarbeid moesten uitvoeren voor de Duitse oorlogseconomie. Van de drie was hij de enige waarvan we weten dat hij het overleefde. Hij stierf als alleenstaande in zijn geboortestad, dertig jaar na zijn vrijlating uit Duitsland.

Ook hier was de beschuldiging van homoseksualiteit - zeer expliciet geformuleerd, in tegenstelling tot de verbale camouflage die de administratie in het eerste voorbeeld had gebezigd - een verzwarende factor of voldoende grond voor adminisvoorber administratieve opsluiting, onder het in een perode waarin bepaade vijwillige homosekstele relaties nog niet door de Vichywet werden beteugeld, sprake van een gecoördineerd bestraffingsbeleid van homoseksualiteit via opsluitingsmaatregelen? Alleen een gedegen archiefonderzoek in andere Franse departementen van de niet-bezette zone zal op termijn duidelijk maken of het een algemene tendens betrof. Door deze ontdekking worden in elk geval onvermoede onderzoeksperspectieven geopend.

BESTRAFFING VAN SEKSUELE COLLABORATIE MET

DE BEZETTER EN LEEGLOPERIJ IN DE NOORDELIJKE ZONE

Dit ruime deel van het Franse grondgebied werd volgens de voorwaarden van de wapenstilstand van 22 juni 1940 onder Duits bewind geplaatst. De voorlopige Franse regering, die vervolgens volmachten kreeg en zich in Vichy vestigde, behield er haar gezag over de staatsadministratie, hoewel de bezetter zijn eigen regels voor ordehandhaving toepaste. Ondanks de Duitse voogdij werd het bestaande rechterlijk-politionele apparaat gehandhaafd en het corpus van de Franse wetten werd niet vervangen door Duitse wetgeving, ook niet wat homoseksualiteit en zedenmisdrijven betrof In theorie zou dit betekenen dater tot de orie zouditbekn wet van augustus 1942 in werking trad niets veranderde aan de wijze waarop homoseksuele praktijken juridisch werden behandeld zolang ze plaatsvonden met wederzijdse toestemming tussen seksueel meerderjarige individuen, en uitsluitend in de privésfeer. Maar uit het recentste onderzoek blijkt dat tussen 1940 en 1944 vanuit de noordelijke zone ongeveer twintig noordelijke zone ongeveer twintis mannen wegens homoseksualiteit
werden gearresteerd en in Duits-

land opgesloten. Tien belandden in concentratiekampen en twaalf in het penitentiaire systeem (Boulligny 2010).

We kunnen twee categorieën onderscheiden. De eerste is de grootste en omvat diegenen die door Duitse militaire autoriteiten werden verweten dat ze ontuchtige betrekkingen hadden (willen) onderhouden met personeel van de bezettingsmacht in Frankrijk. In dat geval spraken Duitse militaire rechtbanken tegen Franse beklaagden of medeverdachten gevangenisstraffen uit op basis van het Duitse recht (artikel 175) - straffen die ze in Duitse gevangenissen moesten uitzitten In andere, (artiklo anekdotischer gevallen werd gedrigd net een beschuldiging van spionage in een homoseksuele context. Bijvoorbeeld in het volgende collectieve dossier betreffende twee individuen, waarover Franse rechercheurs in een rapport van 15 december 1942 zeiden: 'Volgens de inlichtingen aangaande de arrestatiegrond lijkt het te gaan om een zeden-, zwendel- en spionagezaak die door de bezettingsautoriteiten werd behandeld. ${ }^{7}$ De affaire, waarbij een van hen van een verhouding met een Duitse officier werd beticht, had onaangename gevolgen voor de twee vrienden, die alleen gemeen hadden dat ze regelmatige bezoekers waren van dezelfde homoseksuele ontmoetingsplekken in de hoofdstad. Hun opsluiting begon in november 1941, werd voortgezet op verschillende locaties in de regio Parijs en eindigde in januari 1944 in het concentratiek in het concentratiek. len, maar als Transe politiek gevangente driehoek met een F. Op éen uitzondering na was dit het geval voor alle personen die vanuit de bezette of niet-bezette zone naar concentratiekampen werden gedeporteerd en waarvan de voorafgaande opsluiting terugging op een homoseksuele affaire. De enige 'roze driehoek' die vanuit bezet Frankrijk werd gedeporteerd bleek een Duitse soldaat te zijn. Hij werd eind juni 1942 door de Duitse militaire autoriteiten gearresteerd, wegens 'ontucht met mannen' veroordeeld tot vijftien maanden opsluiting, overgeplaatst naar verschillende Duitse gevangenissen en vervolgens naar de concentratiekampen Natzweiler-Struthof en Dachau gevoerd waar hij als ‘\$ 175 ' werd aangeduid. ${ }^{8}$

We hebben op dit ogenblik trouwens maar weet van één Fransman die uit de noordelijke zone werd gedeporteerd, namelijk Gilbert Doublet (1909-1945); het verband met homoseksualiteit blijkt expliciet uit een vermelding op een lijst die transporten van Frankrijk naar Duitsland opsomt ${ }^{9}$ Desondanks werd Doublet in de concentratiekampen Buchenwald en Mittelbau-Dora en het satellietkamp Ellrich ook als 'Franse politiek gevangene' aangeduid. In dat laatste kamp overleed hij op 21 februari 1945. Hoewel we over zijn arrestatie niet veel meer bijzonderheden kennen, zou hij kunnen behoren tot een andere categorie; daarover bestaat minder cijfermateriaal, maar ze is niet minder interessant.

Die tweede categorie heeft veeleer te maken met de strijd tegen 'leegloperij', dat wil zeggen het bestraffen van individuen zonder een vaste baan, vooral nadat begin 1943 de Service du Travail Obligatoire (STO) ten behoeve van Duitsl nadat Franse politie maakte een reeks bezwarende feiten over aan de Duitse autoriteiten.

\section{(7) Archieven van de Préfecture
de Police in Parijs, dossier
betreffende Jean-Henri T. [1906 1974] \& Lucien P. [1904- ?] (8) ITS Arolsen, Josef Bellarmin
D. (1903-1969) - US-vragenlijst voor gevangenen van concentratiekampen - 1.1.6.2 (9) ITS Arolsen, alfabetische lijst van gevangenen uit Compiègne
die aankwamen in het KL Buchenwald op 27.06.1943 -}


De bestraffing van homoseksualiteit in Frankrijk tussen 1940 (vervolg)
(ver

Dit was bijvoorbeeld het geval van de toneel- en filmacteur Hugues Lambert (19081945) en de kunstenaar Jean Giobellina (1918-1943). Volgens de getuigenissen werd de eerste in maart 1943 wegens lanterfanten aangehouden in een gelegenheid die bekendstond om haar homoseksuele klantenkring..$^{10}$ De tweede werd afgeschilderd als een 'notoire homoseksueel die tijdens de bezettingsjaren illegale bals bijwoonde Om die redenen [...] zou hij op 22 augustus 1943 zijn gearresteerd, waarschijnlijk door Franse politieagenten."11 Beiden werden als 'politieke gevangenen' gedeporteerd naar het concentratiekamp Buchenwald en stierven door uitputting: Lambert op naar het concint 7 maart 1945 in het kamp Flossenburg, waarnaar hij was overgebracht; Giobell het satellietkamp Dora, nauwelijks drie maanden na zijn arrestatie in Parijs.

Het geheel van de bezette en onbezette zones in acht genomen speelden wetten van het Vichyregime en zijn politiepraktijken nauwelijks een rol bij het bepalen van de prioriteiten in de strijd tegen homoseksualiteit en de evolutie daarvan tussen 1940 en 1945. De bestraffing buiten de ingelijfde gebieden bleef dus beperkt. Zelf de Duitse bezetter bestrafte maar Fransen wanneer daarbij leden van hun eigen strijdkrachten betrokken waren. Volgens deze logica was het naziregime ook buiten de grenzen veeleer begaan met het behoud van het Duitse volk. Dit ging eveneens op voor bevolkingsgroepen die als deel van het Duitse ras golden; op hen zou het regime in de ingelijfde gebieden de rijkswetten toepassen, ook in de strijd tegen homoseksualiteit.

\section{DE INGELIJFDE ELZAS KOPLOPER IN BESTRAFFINGSTERMEN}

De huidige departementen van de Elzas (Haut-Rhin, Bas-Rhin) en het naburige departement Moselle, die in de negentiende eeuw werden verknipt en geherstructureerd, vormden een gebied dat via het Verdrag van Frankfurt uit 1871 aan het Duitse Keizerrijk was afgestaan. De Duitse staten, kort voordien tot een nieuw rijk verbonden onder de auspiciën van Pruisen, bezegelden zo met een aanzienlijke oorlogsbuit hun overwinning op het Frankrijk van Napoleon III. Door het Verdrag van Versaille werden deze gebieden an heteinde van de Eerste Wereldoorlog weer Frans, naeen werden deze gebieden aan het einde eerste periode waarin de 'tegennatuurlijke ontucht tussen mannen' verboden wa volgens de bepalingen van het keizerlijke wetboek van strafrecht (Hoffschildt 2013). Eind juni 1940 werden ze weerom onder het Duitse jukgebracht - unilateraal ditmaal, vandaar de latere omschrijving 'feitelijke annexatie' - en kwam er opnieuw een einde aan de bijzonder Franse toegeeflijkheid voor mannelijke homoseksuele praktijken. Zodra hij goed en wel in de Elzas was neergestreken, opende de nazibezetter de jacht op homoseksuelen. Aanvankelijk gebeurde dat met het specifieke opzet de bevolking te zuiveren van ongewenste elementen: politieke dissidenten, criminelen en asocialen. In de archieven zijn sporen te vinden van mannen die werden beschuldigd van homoseksuele ontucht (widernatürliche Unzucht/Unzucht zwischen Mänmern), nauwelijks twee manden nadat de troepen van het Rijk de streek hadden inne naw een reeks doortastende maatregelen van het politieapparaat, die losstonden van gerechtelijke beslissingen. Tenzij het bewuste individu na zijn aanhouding en willekeurige opsluiting bij gebrek aan belastende feiten vrijgelaten werd, waren deze maatregelen van tweeërlei aard. Ofwel werd de beschuldigde uitgewezen, ofwel werd hij kortstondig naar het veiligheidskamp Schirmeck-Vorbruck gestuurd als de naziadministratie meende dat hij zijn leven kon beteren via dwangarbeid, want dat was het lot van de gevangen in dat kamp. Dat was het lot van Pierre Seel (19232005). In minder zware gevalen volstonden vaak een warschuwing en een boete 2005). om een einde te maken aan de opsluiting, zoals volmar, die in maart 1941 na 23 dagen opsluiting en omdat zijn vrouw in zijn voordeel getuigde, vaststelde dat zijn politiehechtenis [...] na een waarschuwing werd opgeheven. Hij kreeg te horen dat hij bij recidive te maken zou krijgen met veiligheidsmaatregelen vanwege de politie. ${ }^{12}$

Conform het ritme waarmee de nieuwe meesters de Elzas in de pas deden lopen kreeg de bestraffing een gerechtelijk karakter. In februari 1942 werden de laatste nog geldende Franse wetten definitief vervangen door het Duitse strafwetboek. Zodra de wettelijke basis was gelegd werd gerechtelijke behandeling het belangrijkste strijdmiddel tegen mannelijke homoseksualiteit met honderd gevangenisstraffen tot gevolg. Tussen de 80 en 90 werden uitgesproken dor rechtbanken in Stratsburg, de rest in Colmar, Mulhouse of Saverne. Daarbovenop kwamen nog twintig vonnissen tegen Elzassers die buiten de streek werkten, vooral in de naburige regio's Moselle, Saarland en Baden, zelden in meer afgelegen rechtsgebieden. De straffen schommelden tussen één maand en vier jaar gevangenisstraf voor homoseksuele handelingen met wederzijdse instemming. In ernstige gevallen konden ze oplopen tot vijf of zelfs acht jaar opsluiting, maar dan ging het om seksueel misbruik van minderjarigen. Twee derde van de opgelegde straffen duurde langer dan een jaar, de mediaanwaarde lag rond de anderhalf jaar. Bij sommige uitspraken werd een alternatief voor strafrechtelijke detentie opgelegd, meer bepaald opsluiting in psychiatrische instellingen voor personen met verminderde strafrechtelijke ansprakelijkheid. Het laatste proces voor homoseksueel vergrijp in Stratsbure vanpprar 19 obond plaats op 19 oktober 1944 en eindigde voor de beklaagde met een veroordeling to es maanden gevangenisstraf.

Maar bovenop straffen wegens inbreuk op de bepalingen van de artikelen 175 en 175a (gevallen met verzwarende omstandigheden) werden zoals in Duitsland nog andere buitengerechtelijke maatregelen toegepast, meer bepaald Vorbeugungshaft of 'preventieve opsluiting'. De bedoeling daarvan was te voorzien in mogelijke recidive of anderszins elk individu uit de maatschappij te bannen dat volgens de politie een blijvend gevaar betekende, zelfs als het zijn gevangenisstraf had uitgezeten. Vanaf 1942 vond dat soort opsluiting ook plaats in het veiligheidskamp Schirmeck-Vorbruck en niet in een concentratiekamp zoals al elders in Duitsland gebruikelijk was. De Flzas vormde in dit opzicht een uitzondering die een twintigtal mangen was. De Elys ver in het kamp opnieuw worden geëvalueerd. Feitelijk liep die termijn maar af nadat het
(12) Archieven van het
departement Haut-Rhin, Colmar, 22AL3-8, individueel dossier van Nicolas T. Th (1984-198933) - vrije
vertaling van de auteur. 
kamp vanaf september 1944 naar Duitsland was geëvacueerd. De betrokkenen bleven dus opgesloten in het evacuatiekamp in Gaggenau, dat in april 1945 werd bevrijd. Tot slot ontving het concentratiekamp Natzweiler, hoewel dat eerst uitsluitend was bestemd voor gevangenen die al elders in concentratiekampen zaten, vanaf 1943 ook een paar Elzassers. Ze kwamen de rangen versterken van de meer dan 300 gevangenen die vastzaten vanwege homoseksualiteit. Die laatsten waren grotendeels afkomstig uit het Reich; ze waren sinds mei 1941 ondergebracht in het hoofdkam en in mindere mate in de satellietkampen, tot die in 1945 definitief werden bevijd Als we de represiln Als we de resie de Franse wetgever in 1948 bepaalde voor het toe teerde, komen we tot het volgende overzicht:

Ongeveer 150 mannen, waarvan het overgrote deel Elzassers, kunnen worden gelijkgeschakeld met politiek gedeporteerden (langer dan drie maanden opsluiting in het Reich en/of de ingelijfde gebieden om andere redenen dan van gemeen recht); voor iets meer dan twee derde gaat het om personen die door de rechtbank werden veroordeeld tot gevangenisstraffen van meer dan zes maanden; de anderen (met inbegrip van Pierre Seel) zijn gevangenen die meer dan drie maanden doorbrachten in het ilig . Duitsland

11 Elzassers werden gedeporteerd naar concentratiekampen, de eerste in november 1941 naar Flossenbürg. Ofwel vielen ze onder een preventieve opsluitingsmaatregel van buiten de Elzas, ofwel werden ze op vraag van de autoriteiten van elders overgebracht (Schirmeck of een psychiatrisch ziekenhuis) en 'tot werk verplicht'. Slechts vij van hen werden uitdrukkelijk als homoseksueel aangeduid en droegen de roze driehoek (samen met drie andere personen uit Moselle waren zij de enige Franse gedeporteerden die dat onderscheidingsteken droegen). De anderen staan geregistreerd als 'politieke gevangenen uit de Elzas' of 'gevangenen van gemeen recht'. - Circa 200 personen kregen direct te maken met een andere, niet-deportatiegerelateerde vorm van bestraffing. minder dan drie maanden opsluitins uitwijzin tuch tuchthuis, platsing in een psychatrische instelling in geval van strafrechtelijke ontoerekeningsvataaher. We tellen ook een paar verwante slafiffers bij de echtgenoten of kinderen die hun uitgewezen man of vader volgden.

Onder de directe slachtoffers (ongeveer 370) tellen we in de Elzas minstens 21 overlijdens. Voor het grootste deel waren dat gevangenen van concentratie- en speciale kampen (10), maar ook uitgewezen personen (4, waarvan 3 in een CSS) en gedetineerden die waren opgesloten in gevangenissen (4) of een psychiatrisch ziekenhuis (1). Op het geval van twee Duitsers die bij homoseksuele affaires betrokken waren, werden specifieke vergeldingsmaatregelen toegepast: de eerste werd terechtgesteld krochtens de geheime verordening betreffende morele zuive gesteld krachtr en de politie-eenheden, de andere, een in de Elzas gelegerde Duitse militair, stierf in een strafbataljon waarin hij na degradatie was ondergebracht. Onder de slachtoffers bevonden zich een veertigtal buitenlanders, voor het grootste deel mensen die al voor de oorlog legaal in de Elzas woonden, of ook Duitsers die zich na de annexatie in de Elzas hadden gevestigd of er op doortocht waren, bijvoorbeeld militairen. ${ }^{13}$

Als je mijn gegevens samenlegt met die van Arnaud Boulligny over de andere Franse regio's stel je vast dat de Elzas het zwaarst getroffen was. Uit die streek kwam drie vierde van de circa vijfhonderd personen die te maken kregen met een of andere vorm van repressie, inclusief meer dan honderd Fransen die werden vervolgd voor inbreuken op artikelen 175 en 175 a en die zich op Duitse bodembevonden, alskrijssbevarijgsgevangenen, vrijwilligers of dwangarbeiders. Dit resultaat hoeft niet te verbazen als je rekening houdt met het specifieke karakter van het ingelijfde gebied, hoewe het eveneens ingelijfde departement Moselle dan weer een heel ander lot kende. Moselle is qua oppervlakte en bevolking te vergelijken met Bas-Rhin, maar werd duidelijk minder zwaar getroffen. Vanaf het begin van de annexatie vonden er naar verhouding veel uitwijzingen plaats, maar ze lieten minder sporen na. Bovendien kunnen we niet vaststellen op hoeveel homoseksuelen deze maatregel van toepassing was. We beschikken wel over een handvol gegevens betreffende gerechtelijke bestraffing. Uit het onderzoek dat de geschiedkundige Cédric Neveu in de archieven van het departement deed, blijkt dat een twintigtal mannen strafrechtelijk werden vervolgd en veroordeld, warvan meer dan de helft Duitsers. Onder diegenen uit vervolgd c ver uit Moselle - die behalve voor homoseksualiteit soms ook voor andere zedenfeiten werden berecht - tellen we vijf personen die naar een concentratiekamp werden gedeporteerd, waarvan eén Poolse immigrant. Ze werden eerst opgesloten in Natzweiler, behalve één die direct in de 'priesterbarak' van Dachau terecht kwam (Schwab 2015). Twee keerden niet terug. Dat de situatie in Moselle en de Elzas zo sterk lijkt te verschillen kan liggen aan de bijzonder onvolledige archieven. Maar volgens Cédric Neveu valt een en ander veeleer te verklaren doordat Gauleiter Bürckel en de bevoegde politieoverheden in Moselle maar weinig belang stelden in dit aspect van de strijd tegen 'asocialen' (Neveu 2012, 117-121).

\section{BESLUIT}

De administratieve en territoriale versnippering die de nazibezetter tussen 1940 en 1945 toepaste, is essentieel om de toenmalige bestraffing van homoseksualiteit in Frankrijk te begrijpen. De repressie was het wreedst in de ingelijfde gebieden, en dan vooral in de Elzas. In totaal werden minstens 400 personen door strafmaatregelen getroffen, van willekeurige opsluiting zonder gevolgen tot deportatie naar een concentratiekamp. Die laatste optie kwam weinig voor (minder dan vijf procent van het totaal aantal gevallen). Buiten het ingelijfde gebied was het fenomeen eenvormiger en duidelijk beperkter, hoewel er nog weinig onderzoek is gevoerd naar bijvoorbeeld de administratieve opsluiting in de hele zuidelijke zone.

De bezetting van Frankrijk en de feitelijke inlijving van de Elzas en Moselle door de nazi's vormde een bijzonder gevaarlijke periode voor wie van homoseksualiteit was beschuldigd, maar achteraf kwam er geen terugkeer naar een meer egalitaire 
De bestraffing van
homoseksualiteit in Frankrijk bepalingen ervan werden pas veertig jaar later ingetrokken. Bovendien vormden ze de kiem van een discours dat homoseksualiteit in 1960 als een sociale plaag bestempelde en lagen ze ook aan de basis van discriminerende strafmaatregelen. In die context ontstonden in de jaren zeventig uiteenlopende emancipatiebewegingen die onder meer het afschaffen van de wettelijke discriminatie eisten. Tijdens diezelfde periode werdin Frankrijk geijverd omdevervolging van homoksuen tijdens het periode werd in rankijkgeijvede naziregime te erkennen (Schlagdenhauffen 2011, 148).

Door het wettelijk stigmatiseren van homoseksuele praktijken na de oorlog (het strafbaar maken van vrijwillige homoseksuele betrekkingen tussen personen jonger dan vijftien, maatregelen in de strijd tegen de 'sociale plaag' die homoseksualiteit was) hadden de slachtoffers weinig zin om openlijk te getuigen over hun beproevingen. De enige getuige die naar voren trad, de Elzasser Pierre Seel, werd willekeurig opgesloten, eerst in de gevangenis van Mulhouse en daarna in het veiligheidskamp Schirmeck-Vorbruck. Hij trok de aandacht vanaf de jaren tachtig, kort nadat in de wetgeving de laatste discriminerende bepalingen waren geschrapt, en werd een symbool voor activisten. Zijn getuigenis wierp licht op een bijzonder aspect van het bestraffingsbeleidinde Zlzas en zijn biografie, geschreven in samenwerkingmet de bestive activist Jean Le Bitoux (Seel 1994), is tot op vandaag een van de weinige getuigenissen in het Frans. Doordat hij over een gering aantal bronnen beschikte om zijn beweringen te staven en wellicht ook omdat hij vooral informatieve en militant bedoelingen had, bevatte Seels relaas meer dan vijftigjaar na de feiten onvermijdelijk historische onnauwkeurigheden en herinneringen afkomstig van andere getuigen. Het werk kwam tot stand in een tijdperk waarin de autoriteiten en verenigingen van oud-gedeporteerden nog volhardden in ontkenning. Daardoor en door de leemten in het historisch onderzoek gingen de activisten ervan uit dat homoseksuelen op Frans grondgebied dezelfde straffen kregen als in Duitsland.

Sindsdien is de kennis over het onderwerp toegenomen en vanwege de Franse instellingen is er ook meer erkenning voor deze historische realiteit Toch moesten we tot 2010 acten zweiler-Struthof een herdenkingsplaat kwam ter ere van de 'gedeporteerden om homoseksuele redenen'. En al besteden activistennog altijd bijzonder veel aandach aan het symbool van de roze driehoek als teken van homoseksualiteit in de concentratiekampen, het historisch onderzoek opent nu nieuwe perspectieven. Zo is gebleken dat de metonymische benaming 'roze driehoeken' niet langer het brede spectrum dekt van de gedeporteerden om homoseksuele redenen. Alleen al in het kamp Natzweiler kreeg waarschijnlijk bijna een derde van de gedeporteerden een groene, zwarte of rode driehoek opgespeld (respectievelijk voor 'gevangenen van gemeen recht' 'asocialen' of'politieke gevangenen') Natuurlijk is het ook juist dat zich in dat concentratiekamp de enige Fransen (acht) met een roze driehoek bevond a concenden, allen leiden tot de 'roze driehoeken', zouden we ons beperken tot een minderheid binnen de minderheid van het dertigtal gedeporteerden opgrond van homoseksualiteit (inclusief twaalfvanuit bezet Frankrijk). Overigens zou op die manier oud-volksvertegenwoordige Christian Vanneste gelijk krijgen, die een polemiek opstartte door de vervolging van homoseksuelen een randverschijnsel te noemen dat beperkt bleef tot de drie geannoencent

zouden vooral voorbijgaan aan de verscheidenheid affingspraktijken op het volledige Franse grondgebied, waar vooral de Elzas is getroffen, en waarbij tot nader order haast uitsluitend mannelijke homoseksuelen werden geviseerd. De plicht tot herinnering die militante LGBT-middens en gedachtenisverenigingen inroepen mag niet in de plaats komen van de plicht om geschiedkundig onderzoek te voeren op Europese schaal.

Tot slot valt een zekere overeenkomst op tussen Frankrijk en België zodra beide landen door de nazi's bezet waren. Want ook België kwam (bijna) volledig onder Duitse voogdij te staan (militair bestuur in Brussel), terwijl een grensgebied dat na de Eerste Wereldoorlog terug bij het grondgebied was gekomen in 1940 door nazi-Duitsland werd ingelijfd. In de latste wet die datzelfde jar werd toegevoegd

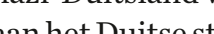
(a) bepalingen van Hitlers verordening d.d. 23 mei de volledige wetgeving van het Reich vanaf 1 september zou gelden in de sector Eupen, Malmedy en Moresnet. We mogen ons dus afvragen wat die verordening betekende voor de strijd tegen homoseksualiteit. Werd die in de bewuste zone gevoerd op een manier die te vergelijken is met wat in de ingelijfde Franse gebieden gebeurde? En wat met de rest van het land?

BIBLIOGRAFIE

- Marc Boninchi, Vichy et l'ordre moral, Parijs: Presses Universitaires de France, 2005, 161-193. - Arnaud Boulligny, 'La déportation de France pour motif dhomosexualité, in Mickä̈l Bertrand (red.), La déportation pour motif d'homosexualité en France - Débat d'histoire et enjeu de mémoire, Lyon: Mémoire active,
2010, 51-2. - Hussein Bourgi, 'Le Mémorial de la déportation homosexuelle', in Le collectif IDEM, Les LGBT font bouger les
sociétés, Parijs: Des Ailes sur un Tracteur, 2015, 356-363.

- Rainer Hoffschildt, Materialsammlung zur Geschichte homosexueller Männer in Elsaj-Lothringen, Hannover, onuitgegeven, 2013.

Maurice Lever, Les bû́chers de Sodome - Histoire des infâmes', Parijs: Fayard, 198.

- Cédric Neveu, La Gestapo en Moselle, Nancy: Serpenoise, 2012.

- Julian Jackson, Arcadie - La vie homosexuelle en France, de l'après-guerre à la dépénalisation, Parijs: Autrement.
$2009,45-55$.

- Régis Schlagdenhauffen, Triangle rose - La persécution des homosexuels et sa mémoire, Parij: Autrement, 2011 - Jean-Luc Schwab, Répression del lhomosexualité en Alsace annexée de fait (1940-1945), masterproef o.lv.
professor Nicolas Stoskopf, Mulhouse: Université de Haute-Alsace, 2015 .

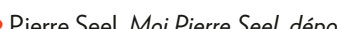

- Eupen, Malmedy en Moresnet - Overeenkomst decreet van de Führer her de Rijkskanselier daterend van 23 mei 1940 [verwijzing naar het officiële blad] treedt hier op 1 september het Reich en de regional wetgeving van Pruisen in voege. Uit:Strafgesetzbuch mit den wichtigsten Nebengesetz Bestimmungen für die neue Reichsgebiete, Berlijn \& München: C.H. Beck'sche verlas (14) Het interview uit februar.
2012 is na te kijken op wrw.
libertepolitique ecom (vanaf

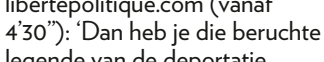
van homoseksuelen. [.... En buiten de drie geannexeerde
departementen heeft er in Frarkrijk geen deeorttatie van
homoseksuelen plaatsgevonden. 